\title{
Ritual Animism and Religious on Sura Thanksgiving Ceremony of Samin Jepang Margomulyo Tribe Community
}

\author{
Nur Alfin Hidayati \\ Universitas SebelasMaret \\ Surakarta, Indonesia \\ nikidanajwasalsabila@gmail.com \\ Herman J. Waluyo \\ Universitas Sebelas Maret \\ Surakarta, Indonesia \\ herman.jwaluyo@yahoo.co.id
}

\author{
Retno Winarni \\ Universitas Sebelas Maret \\ Surakarta, Indonesia \\ winarniuns@yahoo.com \\ Suyitno \\ Universitas Sebelas Maret \\ Surakarta, Indonesia \\ yitsuyitno52@gmail.com
}

\begin{abstract}
The existence of Samin tribe community still becomes a great concern to study. As its identity is unique, independent, and specific in local genius, Samin community is rich in studies with sociology and anthropology perspectives or social anthropology field. This research depicted the animism and religius symbols of thanksgiving ceremony of SaminJepang community, Margomulyo District, Bojonegoro Regency. Samin Jepang Margomulyo is different from other Samin communities in some cities such as Blora, Kudus, Pati, etc. The main distinction is on the existence of MbahHardjoKardi who is sacred by Samin convention as the indigenous leader of Samin generation 4. Since the research aimed at understanding Samin community, the framework for analyzing data employed constructivism theories such as phenomenology, symbolic interaction, and social reality construction. The research method was ethnography, while the data collection technique involved participant and non-participant observation, in depth interview, and document analysis. The data analysis used the stages of description, analysis, and interpretation. The research result indicated that the religious system of Samin community is pantheism or a blend between Animism, Hinduism, and Islam. In short, Samin belief is Saminism or spiritualism. To connect to God, offerings through thanksgiving ceremony are used as mediation. Samin precept on the symbols of thanksgiving ceremony is very pragmatic, practical, and flexible. The most important things in Samin belief (interpretation given by MbahHardjoKardi as the main informant) are the intention and willingness to conduct thanksgiving ceremony, not on its facilities.
\end{abstract}

Keywords—ritual; sura thanksgiving; samin; tribe community

\section{INTRODUCTION}

Samin community gets larger in its number and spreads into other cities such as Bojonegoro, Ngawi, Blora, Pati, and Kudus. So many studies on Samin have been conducted, but most of them came from positivistic paradigm. The research results are beneficial in identifying Samin community objectively in terms of social, cultural, economical, and political systems. As the complement of positivistic paradigm on Samin, constructivist research is urgent for its responsibility.

Some studies on Samin indicated that there has been real transformation in various aspects of Samin lives. However, the thoughts, feeling, experience, and opinion of Samin leader are very limited nowadays. Figuring out the point of view of Samin leader is greatly essential in relation to the existence of Samin community, particularly the one in Jepang Village, Margomulyo District, Bojonegoro Regency.

According to Geertz terminology, SaminJepang people can be categorized abangan group in terms of social, cultural, and belief (religion). They are still in pantheism and very close to mysticism in relation to God. Equipment and interaction model between man and God always used medium during Sura thanksgiving ceremony. Ubarampe (offerings) as the ceremony symbols are in the form of kinds of dishes which have been cooked, shaped, and arranged in certain ways following the rules.

SaminJepang, Margomulyo, Bojonegoro has dissimilar position. It possesses MbahHardjoKardi who genealogically of Samin leadership has direct personification with the previous Samin leader. He felt that he is the legitimate Samin leader from the fourth generation. Besides, in certain level, MbahHardjoKardi is positioned as paranormal by some people (elite and entrepreneur groups).

Besides sociological aspect, cultural element becomes one of society determiner[1] Culture means all things own collectively by people covering social, economy, politic, religion, and so forth [2] C. Cluckhon explains that universally culture contains 7 elements i.e. language, science, social organization, technology, economic system, religion, and art. Cultural study which overlaps with sociology is bridged by social anthropology, whereas the heart of social anthropology 
is ethnography [4][5] Creswell affirms that ethnography is a merger of anthropology and sociology approach [6] The core of ethnography study consists of 6 elements; one of them is cultural theme, particularly, in relation to roles and behaviors in certain society[6]

According to Creswell, there are three main cultural themes focused in ethnography study as the following: 1) individual principles on role and knowledge, 2) individual feeling on role in his culture, 3) the appeared behavior variety. Whereas Spradley (1979) explained that the focus of ethnography are on what people are done (behavior), what they are talking about (language/symbol), is there a relation between what has been done and what should be done, and what artifacts are best made. In short, the focus of ethnography study is all behaviors in certain cultural theme.

\section{METHODOLOGY}

Getting the meaning from a research using symbolic interaction can be done in some ways, for instance: 1) translation from the language delivered by indigenous people and movement from the record into written text, 2) interpretation to make a clear concept done by finding the background and context, 3) extrapolation by emphasizing the ability of human to think something implicit, 4) giving meanings which demands human integrity, sensory, logic, and mind. The research on the symbols of Samin thanksgiving ceremony was based on the qualitative paradigm by ethnography method. This method is very suitable for describing, analyzing, and explaining cultural behaviors of somebody or certain social group[7] The thinking basis of ethnography is learning the human culture systematically. In the phenomenology research, the place of research is flexible, it can be one place and scattered. Related to the research location, the most important thing is the data adequacy to the research objective by considering individuals as the informant. As long as they can give information and explanation well, the location of place is not essential as what had been said by Cresswell (2207:122) as follows:

"For phenomenological study, the process of collecting information involves primarily in-depth interviews (see, e.g. the discussion about the long interview in McCraken, 1988) with as many as 10 individuals. I have seen the number of interviewees referenced in studies range from 1 (Dukes, 1984) up to 325 (Polkinghorne, 1989). Dukes recommend studying 3 to 10 subjects, and Riemen (1986) study included 10. The important point is to describe the meaning of small number individuals who have experienced the phenomenon. With in depth interview lasting as long as 2 ours (Polkinghorne, 1989), 10 subjects in a study represent a reasonable size."
During the research, the researcher interviewed 6 informants who have close relationship with the main informant. Some informants are mentioned in the real names but some are in the nicknames. The data resources for qualitative research according to Arikunto (2010) consist of person, place, and paper; while Spradley only mentions three categories i.e. actor, activity, and place. In this research, the data resources used the combination between Arikunto and Spradley concepts. Thus, there are four data sources namely human, place, activity, and symbol (document). The brief explanation for each category of data sources is as the following:

1. Data source of human consists of the indigenous leader of SaminJepang, Samin youth figure, the Head of Margomulyo District, non-Samin person who intensely interact with Samin community, the descendent of Samin leader, and the teacher of Al Quran. They were taken as the data sources under the consideration of their specific status and roles according to the research objectives.

2. Data source of place involved Jepang Hamlet, Margomulyo Village, Margomulyo District, Bojonegoro Regency with all natural situation and condition as the research has naturalistic character.

3. Data source of activity was the ritual procession of Sura thanksgiving ceremony at Jepang Hamlet, Margomulyo District, Bojonegoro Regency. The recorded activities through observation were obtained by joining the ritual activity of Sura thanksgiving ceremony.

4. Data source of symbol came from the documents of book, recorded picture or photo, and other observation results which related to the research focus. The information from document can add, enlarge or deepen information from individual so that the data are thick and saturated. Besides, the document resources can use triangulation in order to have guaranteed credibility or truth and believability.

The research on the symbols of Samin thanksgiving ceremony by ethnography method, ideally, should be conducted in periods of 1-2 years and should comprise all cultural aspects proposed by C. Kluckhon. Due to the time limitation, the researcher carried out the study for 9 months by focusing on the symbols of Samin thanksgiving ceremony (religious system element).

The research objects of the symbols of Samin thanksgiving ceremony involved:

1. The equipment symbols of Sura thanksgiving ceremony

2. The thanksgiving ceremony process consisting of ceremony situation and context

3. Ceremony events such as the leader, equipments, participants, and activities during the ceremony 
4. The components of thanksgiving ceremony which then became the research questions as the following:

a) What is the main purpose of thanksgiving ceremony?

b) How is the setting of thanksgiving ceremony?

c) Who are the participants of thanksgiving ceremony?

d) How are the interaction rules of thanksgiving ceremony?

e) What messages are delivered in thanksgiving ceremony?

f) How is the thanksgiving ceremony model?

The research was based on emic rules (according to their ways of thought) and ethic (according to the observed empirical situation). The data collection techniques were: 1) participant observation, 2) non-participant observation, 3) indepth interview, and 4) documentation. The sorts of data collected were: 1) the background information of MargomulyoSamin community, 2) the relevant artifact of physical objects for understanding the thanksgiving ceremony, 3) artistic data or literature resources both oral and written, 4) the general knowledge related to the existence of SaminMargomulyo community). In order to have data according to the research objectives, the researcher was as the instrument supported by other instruments such as video camera, field notes, and hand phone.

The observation design comprised the observation of setting, and participants. The former consists of questions such as: 1) where was the thanksgiving ceremony held, 2) when was the ceremony, 3) how were the activities organized, 4) how were the physical aspects of situation during the thanksgiving ceremony, and 5) what belief or values were convinced by Samin community involved in the ceremony. The last observation involved: 1) who took role in thanksgiving ceremony, 2) what is the background of each participant, 3) what is the authority of each participant, and 4) what is the right and duty of each participant. The guided questions for interview in this research were: 1) what is the meaning of thanksgiving ceremony, 2) how was the thanksgiving ceremony conducted, 3) what sort of equipments must be available during the ceremony, 4) must the equipments be available or can them be substituted, 5) who had to conduct the thanksgiving ceremony, 6) who led the ceremony, 7) when was the thanksgiving ceremony, 8) why did they hold the ceremony, 9) where was the ceremony, 10) what things were allowed and not allowed during the ceremony, 11) who involved in the ceremony.

\section{FINDING AND DISCUSSION}

\section{A. SaminJepangMargomulyo Community}

Jepang is a small village located in the middle of teak forest. It is $4 \mathrm{~km}$ from the highway. Since $1 \mathrm{~km}$ from the highway comes into teak forest area directly, the distance of 4 $\mathrm{km}$ becomes so far because whoever will pass the quiet forest.
The community of Jepang village refers to the prototype of Java countryside community which characters are patient and defenseless. Jepang people do not have high mobility. As Samin participant, they did not get used to going out of the vilThe observation design comprised the observation of setting, and participants. The former consists of questions such as: 1) where was the thanksgiving ceremony held, 2) when was the ceremony, 3) how were the activities organized, 4) how were the physical aspects of situation during the thanksgiving ceremony, and 5) what belief or values were convinced by Samin community involved in the ceremony. The last observation involved: 1) who took role in thanksgiving ceremony, 2) what is the background of each participant, 3) what is the authority of each participant, and 4) what is the right and duty of each participant. The guided questions for interview in this research were: 1) what is the meaning of thanksgiving ceremony, 2) how was the thanksgiving ceremony conducted, 3) what sort of equipments must be available during the ceremony, 4) must the equipments be available or can them be substituted, 5) who had to conduct the thanksgiving ceremony, 6) who led the ceremony, 7) when was the thanksgiving ceremony, 8) why did they hold the ceremony, 9) where was the ceremony, 10) what things were allowed and not allowed during the ceremony, 11) who involved in the ceremony lage. In essence, Jepang people draw themselves from the interaction and communication with outer community.

Jepang village has only one road access to outer community and it is surrounded with teak forest area. There are many land ways inside the forest which becomes a route connecting inter-areas inside it needed for forest management process from planting season to cultivation one done by Perhutanior Indonesian State Forestry Company. Most Jepang villagers are rainwater cistern farmers. They are just smallholder because the land they work for belongs to Perhutani. Their farming technique is still in medium level. Although modern technology has penetrated them such as hand tractor, it is still owned by Samin indigenous leader.

The majority of old generation of Jepang community is uneducated while the young generation has studied up to Elementary School level. There are some Samin youths who pursue their studies to High School. There is only one person who studies at Islamic Boarding School supported by the financial from Bojonegoro government. Jepang village has private elementary school but its condition is not well managed and cared.

Samin Jepang Margomulyo community is a part of Samin community which spread and moved from te community center in Randublatung. Based on the history, the emergence of Samin came from Randublatung, exactly from Bapangan Village. There so many Samin communities in some cities such as Blora, Ngawi, Magetan, Pati, Kudus, and Bojonegoro. The development of Samin community in each city is varied. Samin in each city has its own figure and leader. Formally and emotionally, each Samin community does not have close relationship with other Samin communities. Even they claim themselves on who has the legal authority in 
teaching Saminism. When MbahHardjoKardi was asked about the existence of other Samin communities, he spontaneously said:

\begin{abstract}
"Sing mastani Samin teng ngriko-ngriko nggih mangga, wong nyatane buku diwariské têngkulo. Mesthiné yèn ngaku Samin, nggih nggolèki mriki.Wong mbotên tau mrikiniku?!" (Interview with Mbah Hardjo Kardi, on 5 June 2016,in his livingroom)
\end{abstract}

Translation:

"Someone who says Samin is here and there, please go ahead. The fact shows that Samin book was given to me. Someone who confess that he/she is Samin, then he/she has to go here. In fact, no one came here?!"

Based on Samin development, the community can be categorized into two groups namely SaminSangkak and SaminSikep. The former has naive attitude which means that it interacts with outer community while the latter has orthodox attitude because its followers hold Saminism authentically. Badui community can be made as an analogy for Samin community. The analogy will be BaduiLuar for SaminSangkak and BaduiDalam for SaminSingkep.

The number of SaminJepang community, Margomulyo District who has close relationship with Samin generation is 52 people. They are the descendant of MbahSurakarta Kemidin. He has son and daughter namely Sriatun, Munah, HardjoKardi, and Karimah. All of them got married and had sons, daughter, and grandchildren who stayed permanently at Jepang Hamlet and its surrounding.

The result of interviewing Samin indigenous leader (MbahHardjo showed that the forerunner of SaminMargomulyo is from Ngraho, then moved to JepangMargomulyo, grew fast there, and became the core of Samin community. The newcomers who stay at Jepang only become the participants of Saminism.

Socioculturally, SaminJepangMargomulyo came from wongcilik strata $($ wong $=$ people, cilik $=$ marginal $)$ with characters of low education, low mobility, and Java mysticism. Economically, they are categorized in low level economy who mostly work as the farmer of rainwater rice field with medium level farming technology.

\section{B. Sura Thanksgiving Ceremony}

Samin precept confesses the existence of superpower which means that the nature has power and soul. In this context, Samin community is on animism and dynamism nuance. Nowadays, Samin people generally are in syncretism in their spiritual life. There has been a belief conversion from animism-dynamism to Islamism. However, the indigenous leader of Samin still holds the heritage of Saminism firmly.

The thanksgiving ceremony is the proof that Samin people are still in animism-dynamism. They believe than the thanksgiving is a behavior to achieve the condition which safe, peace, and prosperous. Thanksgiving becomes a communication medium between human and God. Samin people convinced that thanksgiving can be the deterrent upon misfortune and disaster; on the contrary, it can give luck and serenity.

The thanksgiving ceremony in Sura month has strategic meaning for Samin people, particularly for Samin leader. Basically, it is a prayer to them. The ceremony is conducted according to wêton (Javanese day of birth) of man who wants to have it. It is suited with what had been said by MbahHardjoKardi as the following: 'dipilihwiwitmêrtapaingguogarba: oranyilihduwèkétanggané'. The translation is 'the day is chosen since the man was in uterus: not borrowing from others'. (Interview was on 23 September 2015, at 20.30, at MbahHardjoKardi's house, while having Sura Thanksgiving ceremony).

Sura thanksgiving ceremony becomes a cultural behavior of Samin people which has spiritual and social dimensions. Spiritually, they believe that Sura month is the right time to beg life salvation for human and peace as well as safety for people. In the social dimension, this ceremony is a medium for gathering in one place, while the leader is responsible for the ceremonial process. He has the duty of ngujubke (presenting the intention of thanksgiving through certain arrangement) and prays.

Sura thanksgiving ceremony in Samin culture is very crucial for everyone to conduct, particularly for someone who has social responsibility such as governmental officer or nonformal leader. Samin indigenous leader always encourage the Head of Regency, as the representation of state, to do Sura thanksgiving ceremony in order to have safety and prosperity. He underlined this purpose by saying:

"Kula mbantu dongakké kajêngé negarané aman, têntrêm, mbotên kisruh.Nèk purunnggih monggo. Nèk mbotên, nggih mbotên nopo-nopo. Ning nggih mbotên ngajèni ndara Surandika (Samin Surasentika-pen) sing berjuang ngadhêpi Landa. Empun merdi kambotên dijaga" (Interview with Mbah Harjo Kardi was on 5 June 2016 in his living room)

Translation :

"I pray for this country safe and peace, without cheos. If you let me do it, I am happy. If you do not want it, never mind. If you choose the last choice, it means that you ignore Surandika (SaminSurasentikapen) who devoted his life against Dutch. This country is independent now, but you do not care about it"

If there is someone from outer Samin community wants to have Sura thanksgiving ceremony, then the procession will be at the house of Samin indigenous leader. From the preparation or ubarampeof ceremony to the procession must 
be under Samin leader's supervision. If Samin people want to have the thanksgiving ceremony, then it can be carried out at their own houses, but they have to invite Samin leader as the head of ceremony to do ngujubke.

\section{The Equipment Thanksgiving Ceremony}

Thanksgiving ceremony means cultural ritual which has spiritual dimension. In the traditional Javanese society, it becomes a falling down behavior. It serves as communication and prayer medium to God for obtaining protection and life happiness. Historically, thanksgiving ceremony is a pre-Islam cultural heritage, especially on Animism and Hinduism.

Generally, thanksgiving ceremony in Java culture always presents some equipment. The main requirements are black and white porridge, cone rice, ingkung (roasted chicken) and kuluban (dry-cooked vegetables). The supporting equipment is fruit (Raja banana-2 units), traditional cakes, coffee, and tea. Each region has slightly different varieties which depend on the surrounding custom and sub-culture.

Samin indigenous leader has flexible attitude in terms of thanksgiving ceremony equipment. He said that the essence of ceremony is not on the facilities but on the intention and willingness to conduct it. The equipments of ceremony are not rigid but adaptable to the real condition as what had been said by him as follows "menawientênénamungkuluban, nggihnikumawon, mbotênmenopo". The translation is "if you only have kuluban, you can use it". (Interview with MbahHardjoKardi was on 5 June 2016, in his living room). If in Sura month, there is no community leader or officer carry out thanksgiving ceremony, the Samin leader will conduct it on behalf of his name.

\section{The Proses of SuraThinksgivingof SaminJepangMargomulyo}

Sura thanksgiving ceremony is annual event conducted at the house of indigenous leader of SaminJepangMargomulyo. This event becomes crucial moment for Samin community for three reasons. First, $t$ he thanksgiving ceremony portrayed a ritual of Saminism precept. Second, it became a place for meeting and greeting all Samin people. Last, it went as a spirit upon the belief of salvation, peace, and safety for the next life.

Sura thanksgiving ceremony of
SaminJepangMargomulyo community, essentially, is like a ceremony of bersihdesa (bersih = clean, desa = village) at nonSamin Javanese community. It is a ceremony to clean and keep the village from evil disruption. The thanksgiving ceremony of SaminJepang which held in the house of indigenous leader is accompanied by entertainment starting from a simpler thing (tape recorder) to onstage entertainment (campursari $=$ traditional Javanese music and song). Since the social and culture of SaminJepangMargomulyo is unique and specific, the government always pays attention and participates for Sura thanks giving ceremony.

The ceremony usually is held at night, after maghrib (around 6 p.m.) all Samin community gather at the indigenous leader's house. They sit along the wall and the ceremony is started by presenting ubarampe located on the floor in the middle of the room. The indigenous leader says the intention and essence of ceremony and then followed by prayer (at Sura thanksgiving ceremony in 2015, the intention of ceremony was delivered by Mr. Jeki who is the civil servant of district serving as the field instructor of Margomulyo District as well as MbahHardjo's student).

After praying, the top of tumpeng(cone rice) and few dishes are placed on the plate which then brought by Samin indigenous leader to special room functioning as a self-pray. The rest of food for ceremony is eaten by all attendants completed by other food which have been prepared previously. All the participants eat together while they are listening and watching the entertainment. The condition of ceremony resembles a village party.

\section{CONCLUSION}

After Thanksgiving in Saminism precept becomes a relation medium between human and God. It serves as a medium for praying and asking to God. It also functions as tribute means to ancestors. The essence of thanksgiving ceremony is begging for salvation, welfare, safety, and life happiness.

Sura thanksgiving ceremony does not only have spiritual value (cultural dimension) but also strategic social-political meaning. Spiritually, this ceremony started from the belief upon Saminism precept which is magic-transcendental. In terms of social-politic, this ceremony serves as a place for gathering and recognition that MbahHardjo as Samin leader is still confessed by people both insider and outsider.

\section{ACKNOWLEDGMENT}

Acknowledgments to all parties who assist data collection and especially for the samin community in japan village MargomulyoBojonegoro, east java Indonesia

\section{REFERENCES}

[1] Basrowi\&Sukidin. (2002). MetodePenelitianKualitatif: PerspektifMikro. Surabaya: InsanCendekia.

[2] Creswell, John W. (1997). Qualitative Inquiry and Research Design: Choosing Among 5 Traditions. London: Sage Publications.

[3] Eriyanto. (2002).Analisis Framing. Yogyakarta: LKIS.

[4] Hidayati, NurAlfin. (2015). PendidikanKarakterdalamBudayaSamin (StudiLapangan di DesaJepangKec. MargomulyoBojonegoro). Bojonegoro: IKIP PGRI Bojonegoro.

[5] Ihromi, T.O. (1990).Pokok-PokokAntropologiBudaya. Jakarta: Gramedia.

[6] Koentjaraningrat. (2000). PengantarIlmuAntropologi. Jakarta: RinekaCipta.

[7] Muhartoyo. (2007). Introduction to Research Methodologies in Language Studies. Lingua Cultura.1(1). 11-18.

[8] Mulyana, Deddy. \&Solatun. (2008). MetodePenelitianKomunikasi. Bandung: RemadjaRosdaKarya.

[9] Mulder, Niels. (2001). MistisismeJawa: Ideologi Di Indonesia. Yogyakarta: LKiS. 
[10] Prihadi. (2015). StrukturBahasaNamaPedusunan di Daerah Istimewa Yogyakarta: KajianAntropolinguistik. LITERA. 14(2). 307-316.

[11] Ritzer, George, \& Douglas J. Goodman. (2009). TeoriSosiologi. Yogyakarta: KreasiWacana.

[12] Saville, Muriel Troike. (1986). The Ethnography of Communication: An Introduction. Southhampton: The Camelot Press.

[13] Spradley, James P. (1997). MetodeEtnografi. Yogyakarta: PT Tiara Wacana.

[14] Spradley, James P. (1979). The Ethnographic Interview. New York: Holt, Rinehart \& Winston.
[15] Suyitno, Imam. (2006). KomunikasiAntaretnikdalamMasyarakat Tutor Diglosik: KajianEtnografiKomunikasiEtnik Using. Humaniora. 18. 263270.

[16] Suyitno, Imam (1996). RiwayatPerjuangan Ki SaminSurosentiko, Pemerintah Daerah KabupatenBojonegoro, KecamatanMargomulyo, tanpahalaman.

[17] Ibrahim, Faridah, TikaNuraeni, Fauziah Ahmad, Chang PengKee, NormahMustaffa. (2012). BahasaKomunikasi Visual Dan PengantaraanProduk: SatuAnalisisSemiotik. GEMA Online ${ }^{\text {TM }}$ Journal of Language Studies. 12(1). 257-273. 